\title{
SEMEN TRIKALSIUM SILIKAT SEBAGAI BAHAN ALTERNATIF UNTUK PENATALAKSANAAN HIPERSENSITIF DENTIN (Kajian Pustaka)
}

\author{
Sinta Deviyanti* \\ *Bagian Konservasi FKG UPDM(B) Jakarta
}

\begin{abstract}
ABSTRAK
Hipersensitif dentin adalah rasa sakit yang timbul khususnya sebagai respon terhadap rangsangan suhu, uap, kimiawi, taktil atau osmotik pada dentin yang terbuka. Hal ini berkaitan dengan terbukanya dentin karena hilangnya email oleh proses abrasi, erosi atau terbukanya permukaan akar gigi akibat resesi gusi atau perawatan periodontal. Rangsanganrangsangan ini akan menyebabkan pergerakan cairan dentin di dalam tubuli dentin yang terbuka sehingga menimbulkan eksitasi saraf dan rasa sakit. Rasa sakit yang timbul pada hipersensitif dentin memiliki variasi sifat yang ekstrim mulai dari kisaran intensitas tidak nyaman sampai sakit sekali. Meskipun berbagai pilihan perawatan menyatakan keberhasilannya dalam menghilangkan keluhan hipersensitif dentin, saat ini belum ada satupun bahan desensitisasi yang dianggap ideal untuk penatalaksanaan kondisi ini. Semen trikalsium silikat kini telah diperkenalkan sebagai bahan kedokteran gigi yang bersifat bioaktif dan biokompatible. Reaksi hidrasi dari semen trikalsium silikat dengan air akan membentuk kalsium hidrat silikat dan reaksi pengerasan. Selama proses hidrasi, bahan ini tetap mampu meresap ke dalam tubuli dentin dan berpotensi memicu penutupan tubuli melalui pengendapan kristal hiroksiapatit. Penutupan tubuli dentin merupakan hal utama yang penting untuk desensitisasi. Penelitian secara in vitro pada semen kalsium silikat telah menunjukkan efektivitasnya dalam mengurangi permeabilitas dentin dan penutupan tubuli. Penggunaan semen trikalsium silikat secara klinis sebagai bahan desensitisasi, layak dipertimbangkan sebagai alternatif penatalaksanaan hipersensitif dentin.
\end{abstract}

Kata kunci : semen trikalsium silikat, hipersensitif dentin, tubuli dentin, penutupan tubuli, permeabilitas dentin

\section{ABSTRACT}

Dentinal hypersensitivity is defined as pain arising from exposed dentine typically in response to thermal, evaporated, chemical, tactile or osmotic stimuli. It is associated with exposure of dentine due to loss of enamel by processes such as abrasion, erosion or denudation of the root surface by gingival recession or periodontal treatment. These stimuli causing dentinal fluid movement within exposed dentinal tubules leading to nerve excitation and pain. The pain arising from dentinal hypersensitivity is extremely variable in character, ranging in intensity from mild discomfort to extreme severity. Although various treatment options have claimed success in relieving dentin hypersensitive, at present , no single desensitizing agent maybe considered to be ideal for this condition. Recently, tricalcium silicate cement have been introduced to the bioactive and biocompatible dental material. The hydration reaction of tricalsium silicate cement with water leads to the formation of calcium silicate hydrate and solidification reaction. During the hydration process, the material may still be able to permeate into the dentinal tubules with the potential to initiate tubule blocking trough deposition hydroxyapatite crystal . Occlusion of dentinal tubules appears to be of prime importance to desentization. Study in vitro of the calcium silicate cement application was determined to be effective on dentine permeability reduction and tubules occlusion. The clinical use of tricalsium silicate cement as desensitizing agent should be considered for dentine hypersensitivity alternative treatment.

Key words: tricalcium silicate cement, dentine hypersensitivity, dentinal tubulus, tubules occlusion, dentine permeability

\section{PENDAHULUAN}

$\mathrm{H}$ ipersensitif dentin merupakan rasa sakit yang lazim dialami pada gigi dengan kondisi dentin yang terbuka dan bukan berasal dari kerusakan atau kondisi patologis gigi. ${ }^{1,2}$ Terbukanya dentin dalam hal ini biasanya disebabkan oleh hilangnya email oleh proses abrasi, erosi atau terbukanya permukaan akar gigi akibat resesi gingiva atau perawatan periodontal. ${ }^{1}$ Hipersensitif dentin hingga saat ini masih menjadi masalah dan tantangan di bidang kedokteran gigi karena merupakan gangguan rasa sakit yang lazim dijumpai dengan keterlibatan faktor etiologi yang beragam dan sering menjengkelkan penderitanya. Upaya penatalaksanaan dengan berbagai teknik dan bahan 
yang disarankan, masih dianggap belum memadai dan memuaskan antara lain dalam hal efisiensi dan efektivitasnya. Hingga saat ini belum ada upaya penatalaksanaan yang dianggap dapat menjadi standar terbaik ${ }^{2,3,4}$. Hal ini akan menimbulkan masalah fisik maupun psikologis pada penderitanya. Lebih lanjut, kondisi ini akan juga dapat berdampak negatif pada kualitas hidup penderitanya terutama berkaitan dengan pemilihan diet, pemeliharaan kebersihan gigi yang optimal termasuk aspek estetik. ${ }^{3}$

Berdasarkan fakta tersebut diatas, hingga saat ini masih terus dilakukan berbagai upaya mencari dan mengembangkan alternatif bahan maupun teknik terkait penatalaksanaan hipersensitif dentin. Salah satu bahan alternatif terbaru yang mulai dikembangkan melalui berbagai penelitian dalam upaya penatalaksanaan hipersensitif dentin yaitu semen trikalsium silikat yang bersifat bioaktif dan biokompatible. Bahan ini diketahui dapat membentuk kalsium silikat hidrat pada reaksi hidrasi dengan air dan mampu meresap ke dalam tubuli dentin sehingga berpotensi mengurangi permeabilitas dentin dan menutup tubuli dentin bila diaplikasikan ke permukaan dentin yang terbuka pada kasus hipersensitif dentin. ${ }^{5,6,7}$

Tujuan penulisan makalah ini adalah untuk memberi informasi dan menambah wawasan pembaca khususnya praktisi di bidang kedokteran gigi terkait semen trikalsium silikat sebagai bahan alternatif untuk penatalaksanaan hipersensitif dentin. Manfaat penulisan makalah ini diharapkan dapat menjadi dasar pertimbangan pembaca dalam memilih bahan alternatif yang lebih efektif, aman dan efisien untuk penatalaksanaan dentin hipersensitif sehingga dapat membantu meningkatkan keberhasilan penatalaksanaan hipersensitif dentin.

\section{KAJIAN PUSTAKA}

\section{Pengertian, Prevalensi, Epidemiologi dan Gejala Klinis Hipersensitif Dentin}

Hipersensitif dentin merupakan rasa sakit yang timbul khususnya sebagai respon terhadap rangsangan suhu, uap, kimiawi, taktil atau osmotik pada dentin yang terbuka. Rasa sakit yang timbul pada hipersensitif dentin tersebut, bukan berasal dari kerusakan atau kondisi patologis gigi. ${ }^{1,2}$ Prevalensi hipersensitif dentin dari beberapa penelitian pada populasi dewasa berkisar antara 5-85\% ${ }^{3}$ dan 2-74\%. ${ }^{8}$ Prevalensi hipersensitif dentin berkisar antara 60-98\% juga dilaporkan terjadi pada pasien yang memiliki riwayat penyakit periodontal. Prevalensi pada populasi di United Kingdom, dilaporkan mencapai $69 \% .^{9}$

Hipersensitif dentin paling banyak diderita pada kelompok usia 20 sampai 30 tahun dan meningkat kembali pada kelompok usia 50 tahun. Kondisi ini biasanya meliputi permukaan fasial di dekat leher gigi. ${ }^{1}$ Penderita hipersensitif dentin dengan jenis kelamin wanita lebih sering dijumpai, diduga terkait dengan faktor diet dan kebersihan mulut. ${ }^{3}$
Karakteristik gejala klinis hipersensitif dentin pada dentin yang terbuka berupa rasa sakit yang tajam dengan durasi pendek sebagai respon terhadap rangsang suhu, uap, taktil, osmotik, kimia dan bukan berasal dari kerusakan atau kondisi patologis gigi. ${ }^{2}$

\section{Etiologi Hipersensitif Dentin}

Dentin hipersensitif memiliki beragam etiologi. Data atau informasi yang perlu diperiksa dari penderita untuk mengetahui etiologi hipersensitif dentin tersebut diantaranya adalah riwayat kesehatan dan sosial, gaya hidup, obat-obatan dan suplemen yang dikonsumsi, kebiasaan makan dan diet serta kebersihan rongga mulut. Kondisi rongga mulut yang harus disingkirkan sebelum menetapkan diagnosis hipersensitif dentin, meliputi trauma oklusal, karies, kerusakan restorasi, gigi retak atau pecah, potensi patologis pulpa reversible atau irreversible serta kondisi gingival. ${ }^{2}$

Etiologi utama dari hipersensitif dentin adalah hilangnya struktur email pada mahkota gigi serta resesi gingiva (penurunan gusi) yang menyebabkan terbukanya daerah akar gigi. Hilangnya struktur email gigi dapat dijumpai misalnya pada kondisi abrasi, erosi, atrisi dan absfraksi. Struktur email juga bisa hilang akibat cara menyikat gigi yang salah (terlalu keras), konsumsi makanan asam yang berlebihan, terasahnya gigi akibat kebiasaan parafungsional atau stress serta adanya faktor iatrogenik selama prosedur preparasi dan restorasi gigi. Kebiasaan mengkonsumsi makanan dan minuman seperti buah-buahan, teh lemon, jus buah dan soft drink juga dapat menyebabkan erosi gigi dan dentin hipersensitif. ${ }^{2,9}$

Resesi gingiva sebagai etiologi hipersensitif dentin, dapat terjadi karena penyakit periodontal serta cara menyikat gigi yang salah atau terlalu keras. Beberapa prosedur tindakan perawatan gigi (preparasi crown, scalling dan root planning) maupun bedah (misalnya bedah periodontal untuk mengurangi kedalaman pocket), juga dapat menyebabkan perubahan posisi normal gingiva di perbatasan antara mahkota dan akar gigi. Prosedur pemutihan gigi (bleaching) eksternal juga telah dilaporkan dapat menjadi faktor etiologi hipersensitif dentin., ${ }^{1,2,9}$

\section{Teori Mekanisme Hipersensitif Dentin}

Teori yang paling banyak diterima sebagai penjelasan tentang mekanisme timbulnya rasa sakit pada hipersensitif dentin adalah teori hidrodinamik yang dikemukakan oleh Brannstorm pada tahun 1963 melalui pengamatan secara histologis dan fisiologis. Teori hidrodinamik menyatakan bahwa mekanisme timbulnya rasa sakit pada hipersensitif dentin diakibatkan oleh aspirasi odontoblas ke dalam tubuli dentin sebagai efek yang segera terjadi akibat rangsang pada dentin yang terbuka, selanjutnya menyebabkan pergerakan cairan dentin dalam tubuli yang sangat cepat dan kuat melalui aksi kapiler sehingga menstimulasi serabut saraf tipe-A disekitar odontoblas dan memicu respon struktur 
pembuluh darah dan saraf pada pulpa gigi. ${ }^{2,10}$ Berbagai bukti hasil penelitian juga telah mengindikasikan bahwa pergerakan cairan dalam tubuli dentin menjadi dasar timbulnya rasa sakit pada hipersensitif dentin. ${ }^{11}$ Penelitian selanjutnya terkait mekanisme timbulnya rasa sakit pada hipersensitif dentin, telah membuktikan keberadaan perangkat sensorik dari odontoblas yang berperan dalam penerusan sensorik dari rangsangan terhadap gigi ${ }^{10}$. Kini telah diketahui bahwa rasa sakit yang ditimbulkan oleh rangsangan panas, dingin, semprotan udara dan probing dengan ujung sonde, merupakan hal yang umumnya dapat menyebabkan perpindahan cairan dalam tubuli dentin pada kasus hipersensitif dentin. Teori hidrodinamik juga menjelaskan bahwa rasa sakit pada hipersensitif dentin berhubungan dengan stimulasi gigi sensitif yang pada akhirnya melibatkan transduksi mekanik. ${ }^{11}$

\section{Penatalaksanaan Hipersensitif Dentin Secara Umum}

Selain menggunakan bahan-bahan desensitisasi untuk mengurangi permeabilitas dentin, penatalaksanaan hipersensitif dentin secara umum saat ini diarahkan pada pengurangan diameter fungsional atau penutupan dari tubuli-tubuli dentin untuk membatasi pergerakan cairan dalam tubuli dentin dan menghambat respon saraf pulpa. Upaya-upaya penatalaksanaan yang dapat dilakukan oleh pasien di rumah atau oleh dokter gigi di klinik untuk mencapai tujuan tersebut diantaranya :2,7,11,12

1. Pembentukan smear layer pada hipersensitif dentin melalui burnishing pada daerah akar gigi yang terbuka.

2. Aplikasi bahan desensitisasi yang dapat membentuk presipitat atau endapan di dalam tubuli dentin (misalnya komponen oxalate, potassium nitrate, potassium citrate, potassium chloride, garam stronsium dan sodium fluoride dalam bentuk sediaan pasta gigi, obat kumur dan permen karet).

3. Aplikasi bahan resin adesif yang dianggap mampu membentuk presipitat protein plasma didalam tubuli dentin sehingga menutup tubuli dentin (misalnya HEMA atau hydroxyethyl methacrylate).

4. Aplikasi bahan bonding dentin untuk menutup tubulitubuli dentin

Literatur lain juga menyebutkan upaya-upaya penatalaksanaan dari hipersensitif dentin selanjutnya dapat berupa penggunaan obat anti-inflamasi (misalnya kortikosteroid), aplikasi varnish fluoride, aplikasi bahan remineralisasi CPP-ACP (casein phosphopeptide amorphous calcium phosphate), aplikasi bioglass (mampu membentuk lapisan apatite yang menutup tubuli dentin), penggunaan bahan restorasi (tumpatan), penempatan mahkota tiruan, periodontal soft tissue grafting dan penggunaan laser., ${ }^{1,2,3}$

\section{Komposisi, Sifat dan Fungsi Semen Trikalsium Silikat di Bidang Kedokteran Gigi}

Semen trikalsium silikat $\left(\mathrm{Ca}_{3} \mathrm{SiO}_{5}\right.$ atau $\left.\mathrm{C}_{3} \mathrm{~S}\right)$ merupakan bahan semen yang kini mulai diperkenalkan di bidang kedokteran gigi. Semen trikalsium murni memiliki kandungan trikalsium silikat 99\%, diproduksi melalui metode sol-gel dari pemurnian bahan-bahan seperti kalsium oksida dan silikon oksida. Sol-gel akan diubah menjadi bentuk ceramic melalui pemanasan pada suhu rendah. Komposisi semen trikalsium silikat murni yang juga sebagai komponen utama dalam sement Portland (68\%) dan MTA atau Mineral Trioxide Aggregate (53,1\%), bila ditambahkan air akan menghasilkan kalsium hidrosilika amorf $(\mathrm{CaO})\left(\mathrm{SiO}_{2}\right) \cdot\left(\mathrm{H}_{2} \mathrm{O}\right)$ serta kristal kalsium hiroksida $\left(\mathrm{Ca}(\mathrm{OH})_{2}\right){ }^{6,13}$

Semen trikalsium silikat bersifat bioaktif dan biocompatible karena mampu menginduksi pertumbuhan dan diferensiasi sel serta mengendapkan kristal hidroksiapatit di permukaannya. ${ }^{7,13}$ Pelepasan kalsium hidroksida dari semen ini menyebabkan $\mathrm{pH}$ semen menjadi basa. Walaupun bubuk semen trikalsium silikat murni dan semen Portland sama-sama mengandung komponen utama kalsium dan silikon, kandungan kalsium pada partikel bubuk semen trikalsium silikat lebih tinggi dibandingkan pada semen Portland. Partikel bubuk semen trikalsium silikat murni juga berukuran lebih halus dibandingkan semen Portland serta tidak mengandung komponen aluminium. Pencampuran bubuk semen ini dengan dengan deionized water, mampu menginduksi pembentukan lapisan mineralisasi yang memiliki ikatan kuat terhadap matriks dentin dari struktur gigi. Hasil hidrasi semen ini juga mampu membentuk endapan kristal hidroksiapatit dengan kandungan kalsium yang tinggi di bagian permukaan semennya. .,7,13 $^{2}$

Semen Portland kalsium silikat hydraulic seperti ProRoot MTA (Dentsply,USA), Tech Bios, ealer (Isasan,Italy), MTA(Angelus,Brazil) dan semen kalsium silikat lainnya, memiliki fungsi pada berbagai aplikasi klinis di bidang kedokteran gigi meliputi perawatan root end filling, perbaikan perforasi akar gigi, kaping pulpa, dan apeksifikasi. Penelitian terbaru menjelaskan bahwa semen berbahan dasar trikalsium silikat juga dapat berfungsi untuk penatalaksanaan kasus hipersensitif dentin serta dianggap mampu menggantikan peran MTA karena kesamaan komposisi dan bioaktifitas bahannya. ${ }^{5,7,13}$

\section{Efektifitas Aplikasi Semen Trikalsium Silikat Sebagai Bahan Penatalaksanaan Hipersensitif Dentin}

Penelitian in vitro oleh Dong Z, dkk. menggunakan berbagai ratio atau konsentrasi campuran bubuk semen trikalsium silikat dan deionized water yang diinkubasi pada saliva buatan selama 7 hari, telah mendukung asumsi semen trikalsium silikat efektif sebagai bahan untuk penatalaksanaan hipersensitif dentin. Pasta semen trikalsium silikat (dari campuran bubuk semen tersebut dengan air) dalam penelitian tersebut, diulas menggunakan kapas pada spesimen dentin lalu didiamkan selama 3 menit dan dibersihkan dengan kapas kering serta dibilas dengan air. Analisa 
SEM (Scanning Electron Microscopy) dalam penelitian tersebut, menunjukkan bahwa pengulasan pasta semen trikalsium silikat dengan ratio yang makin meningkat, akan menghasilkan endapan lapisan mineralisasi homogen menyerupai kristal hidroksiapatit yang menutupi permukaan dentin hingga berpenetrasi menutup tubuli dentin dengan kedalaman yang makin meningkat. Campuran bubuk dan air pada ratio $1,2 \mathrm{mlg}^{-1} \mathrm{dan}_{1,5} \mathrm{mlg}^{-1}$ menunjukkan penutupan tubuli dentin secara berurutan sedalam $1,2 \mu \mathrm{m}$ dan $4-6 \mu \mathrm{m} .^{6}$

Penelitian sebelumnya yang mendukung hasil penelitian Dong Z,dkk. juga telah dilakukan terhadap semen trikalsium silikat yang dicampur air, tampak membentuk pasta halus dan plastis yang dapat diaplikasi dan tersebar di permukaan dentin sehingga dapat menutup tubuli dentin yang terbuka seperti pada kasus dentin hipersensitif. ${ }^{14}$ Penelitian terbaru terkait efektifitas semen trikalsium silikat sebagai bahan untuk penatalaksanaan dentin hipersensitif, telah membuktikan bahwa penggunaan sistem silica atau komponen biomaterial silica pada semen trikalsium silikat, terbukti mampu menutup tubuli dentin secara nyata dan mengurangi permeabilitas dentin sehingga dapat berfungsi untuk mengurangi keluhan rasa sakit pada kasus hipersensitif dentin.?

\section{PEMBAHASAN}

Semen trikalsium silikat sebagai bahan bioaktif dan biocompatible, kini telah dikembangkan sebagai bahan alternatif baru untuk penatalaksanaan hipersensitif dentin yang juga aman dalam mencegah berbagai kerusakan jaringan gingiva. Semen trikalsium silikat dianggap sebagai bahan remineralisasi biomimetik dentin karena kemampuannya membentuk kristal hidroksiapatit pada simulasi perendaman dalam berbagai cairan tubuh termasuk darah dan saliva. ${ }^{7}$

Penggunaan sistem silica atau biomaterial silica sebagai komponen semen trikalsium silikat yang terbukti mampu menutup tubuli dentin secara nyata dimungkinkan karena terjadi pelepasan kalsium hidroksida dari proses hidrasi semen ini serta pembentukan endapan kristal hidroksipatit di permukaan dentin maupun di dalam tubuli dentin yang berperan menutup tubuli-tubuli dentin dan mengurangi permeabilitas dentin sehingga dapat berfungsi untuk mengurangi keluhan rasa sakit pada kasus hipersensitif dentin. ${ }^{7}$ Fakta tersebut juga didukung oleh penelitian Camilleri J, dkk. tentang karakterisasi dan kinetik hidrasi dari semen trikalsium silikat murni yang menjelaskan bahwa proses hidrasi dari semen ini saat bereaksi dengan air, akan membentuk Calsium-Silicate-Hydrate (C-S-H) dan kalsium hiroksida yang lebih banyak serta endapan kristal dengan kandungan kalsium yang lebih tinggi dibandingkan semen Portland. Kandungan kalsium yang tinggi pada semen trikalsium silikat murni ini selanjutnya akan menghasilkan endapan kristal kalsium fosfat dan hidroksiapatit yang lebih banyak di permukaan semen bila berkontak dengan larutan fisiologis. Pengendapan kristal ini merupakan dasar fisiko-kimia dari bioaktifitas semen trikalsium silikat. Kemampuan pelepasan komponen kalsium hidroksida dan kalsium hidrat silikat pada proses hidrasi semen trikalsium silikat saat bereaksi dengan air, dimungkinkan karena semen trikalsium silikat bersifat bioaktif dan

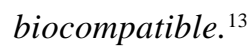

Penelitian lain terhadap semen trikalsium silikat yang dicampur air hingga membentuk pasta halus dan plastis yang dapat diaplikasi dan tersebar di permukaan dentin sehingga dapat menutup tubuli dentin untuk penatalaksanaan hipersensitif dentin, dimungkinkan karena ukuran partikel bubuk semen trikalsium silikat yang sangat halus sehingga mudah untuk masuk ke dalam tubuli dentin yang terbuka untuk membentuk plugs yang ternyata juga tahan terhadap paparan air. ${ }^{14}$

Terbentuknya endapan lapisan mineralisasi homogen menyerupai kristal hidroksiapatit yang menutupi permukaan dentin hingga berpenetrasi menutup tubuli dentin dengan kedalaman yang makin meningkat pada penelitian in vitro oleh Dong Z,dkk. menggunakan berbagai ratio atau konsentrasi campuran bubuk semen trikalsium silikat dan deionized water yang diinkubasi pada saliva buatan selama 7 hari, juga dimungkinkan terjadi melalui mekanisme pertukaran ion. Selain saliva buatan yang diganti setiap harinya pada penelitian in vitro tersebut sehingga dapat menyediakan ion kalsium dan fosfat secara berkelanjutan, pasta semen trikalsium silikat juga dapat melepas sejumlah ion silikat pada saat yang bersamaan. Kondisi ini secara cepat akan membentuk lapisan yang "kaya” kandungan silikat pada permukaan dentin serta menciptakan kondisi ideal untuk nukleasi hidroksiapatit yang selanjutnya mempercepat pengendapan kalsium fosfat dan menyebabkan pertumbuhan lapisan mineralisasi. Pertumbuhan lapisan mineral baru yang memiliki ikatan kuat terhadap matrik dentin pada permukaan dentin yang terbuka atau di dalam tubuli dentin, akan memicu penutupan tubuli yang terbuka. Hal ini akan menurunkan permeabilitas dentin dan pergerakan cairan tubuli dentin sehingga mengurangi keluhan sakit pada hipersensitif dentin. ${ }^{6}$

\section{RINGKASAN}

Semen trikalsium silikat yang bersifat bioaktif dan biocompatible, berpotensi digunakan sebagai bahan alternatif untuk penatalaksanaan kasus hipersensitif dentin karena terbukti mampu membentuk CalsiumSilicate-Hydrate (C-S-H) dan kalsium hidroksida dari proses hidrasinya yang menginduksi pembentukan lapisan mineralisasi menyerupai kristal hidroksipatit di permukaan dentin maupun di dalam tubuli dentin untuk menutup tubuli-tubuli dentin dan mengurangi permeabilitas dentin sehingga dapat berfungsi untuk mengurangi keluhan rasa sakit pada kasus hipersensitif dentin .

\section{DAFTAR PUSTAKA}

1. Suchetha A, Prasad BSK, Apoorva SM, Lakshmi P. 
Dentinal hypersensitivity-a review. India Journal of Dental Sciences.2013;2(5):112-116.

2. Garg SK, Garg S, Mittal S, Yadav K. Dentin hypersensitivity:an enigma. Indian Journal of Dental Education.2013;3(6):139-145.

3. Davari AR, Ataei E, Assarzadeh H. Dentin hypersensitivity : etiology, diagnosis and treatment;a literature review. J Dent Shiraz Univ Med Sci.2013;14(3):136-145.

4. Schmidlin PR, Sahrmann P. Current management of dentin hypersensitivity. J Clin Oral Invest.2013;17:S55-S59.

5. Giovanna GM, Silvia F, David P, Gasparotto G, Carlo P. Calcium silicate coating derived from Portland cement as treatment for hypersensitive dentine. $J$ of Dentistry.2008;36:565-578.

6. Dong Z, Chang J, Deng Y, Joiner A. Tricalcium silicate induced mineralization for occlusion of dentinal tubulus. Australian Dental Jurnal.2011;56:175-180.

7. Gandolfi MG, Iacano F, Pirani C, Prati C. The use of calcium-silicate cement to reduce dentine permeability. J Archived of Oral Biology.2012;57:1054-1061.

8. Que K, Guo B, Jia Z, Chen Z, Yang J, Guo P, A cross sectional study: non caries cervical lesions, cervical dentine hypersensitivity and related risk factors.J Oral Rehabil.2013;40:24-32.

9. Ali S, Farooq I. Dentin hypersensitivity: a review of its etiology, mechanism, prevention strategies and recent advancement in its management. World Journal of Dentistry.2013;4(3):188-192.

10. Larjava H. Oral wound healing: cell biology and clinical management. $1^{\text {st }}$ edition, UK: John Wiley \& Sons Inc,2012:70-73313-315.

11. Hargreaves KM, Berman LH.Cohen's Pathway of the pulp. St.Louis: 11 th edition, Elsevier,2016:532-549.

12. Trushkowsky RD, Godoy FG.Dentin hypersensitivity;differential diagnosis, test and etiology. J Conpendium.2014;2(35):99-103.

13. Camilleri L. Characterization and hydration kinetics of tricalcium silicate cement for use as a dental biomaterial. J Dental Material.2011; xxx : 1-9.

14. Komabayashi T, Spangber LSW.Comparative analysis of the particle size and shape of commercially available mineral trioxide aggregate and Portland cement: a study with a flow particle image analyzer. Journal of Endodontics. 2008;43:94-98. 